\title{
Parity implications for anthropometrical variables, lifestyle behaviors and dietary habits in pregnant women
}

\author{
Influencia de la paridad sobre variables antropométricas, \\ estilos de vida y hábitos alimentarios en mujeres embarazadas
}

\author{
L. Goñi ${ }^{1,2}$, M. Cuervo ${ }^{1,2,3}$, S. Santiago ${ }^{1,2}$, I. Zazpe ${ }^{1}$, J.A. Martínez ${ }^{1,2,3}$
}

\begin{abstract}
Background. Maintaining an adequate health status and appropriate lifestyles during pregnancy is of great importance to prevent adverse outcomes for both mother and baby. The present study aimed to assess the nutritional status, socio-demographic features, lifestyle behaviors and dietary habits of pregnant women in Spain, and to identify the influence of parity on these profiles.
\end{abstract}

Methods. This cross-sectional study included pregnant women from regions all over Spain. The information was collected through a 40 item questionnaire, previously validated, by community health professionals.

Results. The 5,087 pregnant women analyzed had an average age of 31.9 years with an adequate nutritional status. The distribution of the sample was $56 \%$ nulliparous and $44 \%$ multiparous. The nulliparous reported a better self-perceived health status and nutritional balance, and a lower incidence of gestational diabetes mellitus. However, the multiparous showed healthier lifestyle habits (lower rates of smoking and alcohol consumption) and more physically active patterns. Regarding diet, nulliparous pregnant women consumed more dairy products, fresh fruit and nuts, and less bread, rice/pasta/potatoes, meat, sausage and buns/pastries than multiparous pregnant women.

Conclusions. Differences between analyzed patterns were observed in anthropometrical variables, lifestyle behaviors and dietary habits, which may require different nutritional messages to nulliparous as compared to multiparous from a public health point of view.

Keywords. Pregnancy. Parity. Nutritional status. Lifestyle behaviours. Food habits.

\section{RESUMEN}

Fundamento. Durante el embarazo, el mantenimiento de un adecuado estado de salud y estilos de vida, es de gran importancia para prevenir resultados adversos tanto para la madre como para el bebé. El presente estudio tuvo como objetivos evaluar el estado nutricional, características sociodemográficas, estilos de vida y hábitos alimentarios de mujeres embarazadas en España, e identificar la influencia de la paridad sobre estos perfiles.

Material y método. Este estudio transversal incluyó mujeres embarazadas de todas las comunidades autónomas de España. La información se recogió a través de un cuestionario de 40 preguntas, previamente validado, por profesionales de la salud comunitarios.

Resultados. Las 5.087 mujeres embarazadas presentaron una edad media de 31,9 años y un adecuado estado nutricional. De la muestra un $56 \%$ fueron nulíparas y un $44 \%$ multíparas. Las mujeres nulíparas declararon mejor autopercepción de su estado de salud y estado nutricional, y menor incidencia de diabetes mellitus gestacional. Sin embargo, las mujeres multíparas mostraron estilos de vida más saludables (tasas de consumo de tabaco y alcohol más bajas) y un patrón de actividad física más activo. En cuanto a la dieta, las nulíparas consumieron más lácteos, fruta fresca y frutos secos, y menos pan, arroz/pasta/patatas, carne, embutidos y bollos/pasteles que las multíparas.

Conclusiones. Se observaron diferencias entre los grupos analizados en cuanto a variables antropométricas, estilos de vida y hábitos alimentarios, que pueden requerir distintos mensajes nutricionales para mujeres nulíparas y multíparas, desde un punto de vista de Salud Pública.

Palabras clave. Embarazo. Paridad. Estado nutricional. Estilos de vida. Hábitos alimentarios.

\section{An. Sist. Sanit. Navar. 2014; 37 (3): 349-362}

1. Department of Nutrition, Food Sciences and Physiology. University of Navarra. Pamplona. Spain.

2. Centre for Nutrition Research. Faculty of Pharmacy. University of Navarra. Pamplona. Spain.

3. CIBER Fisiopatología Obesidad y Nutrición (CIBERobn). Instituto de Salud Carlos III. Spain.

Recepción: 16 de abril de 2014

Aceptación provisional: 30 de junio de 2014

Aceptación definitiva: 1 de septiembre de 2014

\author{
Corresponding author \\ J. Alfredo Martínez \\ Department of Nutrition, Food Sciences and Physiology \\ University of Navarra \\ Irunlarrea, 1 \\ 31008 Pamplona.Navarra.Spain \\ E-mail: jalfmtz@unav.es
}

Source of funding

This study was supported by the spanish pharmacists council and the University of Navarra. 


\section{INTRODUCTION}

Gestational state leads to anatomical, physiological and biochemical adaptive changes in order to ensure growth and development of the fetus. Thus, energy and most nutrient requirements are increased, so the nutritional status of the mother may be in risk ${ }^{1}$.

Energy undernutrition and micronutrient deficiencies have been related to adverse outcomes for both, mother and baby. Vitamin A, vitamin D, folic acid, vitamin B12 and other antioxidant vitamins are important for reproduction and later normal development of the fetus and the neonate. Moreover, some minerals of crucial interest during pregnancy are calcium, iron and iodine which are involved in maintaining the adequate nutritional status of the mother and the offspring ${ }^{2}$. On the other hand, maternal overweight and obesity are considered health risk factors for mother and fetus. Overweight women are more susceptible to suffer during pregnancy hypertensive events, pre-eclampsia, thromboembolic disorders, gestational diabetes mellitus (GDM), labour induction and caesarean delivery ${ }^{3,4}$. Furthermore, fetal problems include congenital malformations, macrosomia, stillbirth, shoulder dystocia and predisposition for adulthood diseases such as obesity, diabetes mellitus (DM), metabolic syndrome and cardiovascular disease $^{3}$.

Drug-toxicant exposure has been shown to cause marked damage for mother and newborn. Thus, intrauterine growth restriction and low birth weight are the most common effects of maternal smoking, but there are other factors associated such as spontaneous miscarriages, effects on the placenta, structural malformations, stillbirth, sudden infant death syndrome, neurobehavioral effects and metabolic disorders including obesity, elevated blood pressure and DM. Fetal alcohol spectrum disorders is an umbrella term, which include birth defects caused by consumption of alcohol during gestation, including intrauterine growth restriction and developmental delay, among others ${ }^{5}$. Also, illicit drug exposure in pregnancy is associated with maternal and fetal morbidity ${ }^{5}$.

In the same way, regular physical activity has beneficial effects for both of them (mother and fetus). The main maternal benefits are the improvement of cardiovascular function, reduction of the incidence of metabolic diseases (GDM or pre-eclampsia) and regulation on the weight gain during pregnancy ${ }^{6}$. Regarding to the fetus, it has been reported that lower fat mass, greater stress tolerance and neurobehavioral maturation are some of the benefits associated to adequate physical activity during pregnancy ${ }^{6}$.

According to the afore mentioned pathophysiological conditions and lifestyle behaviors, previous studies suggest that parity can have an impact on them ${ }^{7,8}$. However, few studies have been performed in other behaviors of interest during pregnancy. Therefore, the two main aims of the present study were to assess the nutritional status, sociodemographic features, lifestyle behaviors and dietary habits of Spanish pregnant women and to identify the influence of parity on these profiles in order to provide specific messages for these two groups of pregnant women.

\section{MATERIAL AND METHODS}

\section{Subject recruitment}

The current cross-sectional study was conducted between November 2009 and March 2010. The study population consisted of 5,087 pregnant women from regions all over Spain who participated in a national plan of nutritional education (Appendix 1). This program was performed in order to bring information, to preconceptional, pregnant and lactating women, about the importance of how lifestyles and dietary habits could influence the development and health of their children ${ }^{9}$. Participants were recruited by community pharmacists and were specifically asked if they would be willing to take part anonymously in the study. After ensuring that participants had understood the information, only those who voluntarily accepted were enrolled. 
Voluntary completion of the questionnaire was considered to imply verbal informed consent. The survey, which involved an observational questionnaire but not intervention, was conducted with the approval of the Spanish Council of Pharmacist and the board of the Institute of Food Sciences and Nutrition of the University of Navarra, according to the guidelines laid down in the Declaration of Helsinki for anonymous surveys ${ }^{10}$.

Previously, community pharmacists were recruited through the Spanish Pharmacists Council to collect data. In order to obtain consistent results to be compared among participants, all of the interviewers received a training session by videoconference or face to face, and the "application guide", an extensive document with basic information about the survey, which contained instructions to formulate and answer each question ${ }^{9}$. Later, each of the community pharmacists was evaluated throughout a knowledge assessment questionnaire, to test if they had understood the content of the questionnaire in a similar way. This information was also available for all pharmacists involved in the study in a website.

\section{The nutritional survey}

The nutritional questionnaire validated for nutritional status, physical activity profile and dietary habits of pregnant women (Appendix 2); included a total of 40 questions distributed into 6 sections: general information, obstetric data, breastfeeding intention (type and duration), unhealthy lifestyle habits, pathophysiological state and dietary habits ${ }^{11}$.

The section general information included anthropometrical measurements, data about self-perception of health status and nutritional balance, educational level and physical activity. The anthropometrical measurements were taken by community pharmacists (weight, height and middupper arm circumferece -MUAC-), whereas preconceptional weight was self-declared. Body mass index (BMI) was calculated dividing weight by the square of height.
MUAC was measured between the acromion process of the humerus and the olecranon process of the ulna, with the arm relaxed alongside the body, using a flexible and inextensible measuring tape. Anthropometrical and physical activity data collection has been already validated elsewhere ${ }^{11}$. The validity of anthropometrical measurements was assessed by testing the accuracy of measurements collected by community pharmacists and comparing them to measurements collected by trained research staff ${ }^{11}$. The physical activity questionnaire, that collects the number of hours spent in lying, sitting and moving activities since women were pregnant, had demonstrated validity against other physical activity questionnaire previously validated $^{11}$.

Obstetric data comprised the type of pregnancy (single or multiple pregnancy), gestational age, parity and previous miscarriages. Information about smoking, alcohol consumption and illicit drugs at the time of the interview was collected in the section concerning unhealthy lifestyle habits. Regarding to the section pathophysiological state, women were asked about suffering a severe disease, presence of GDM (with confirmed medical diagnosed) and follow a special diet (low calorie, low fat, low carbohydrates or low sodium diets, and any type of vegetarian diets).

Diet information was collected by a validated Food Frequency Questionnaire (FFQ) in which basic foods were classified into twelve food groups, where 4 responses were possible: daily, weekly, monthly or never ${ }^{11}$. Pregnant women were asked to report their food habits during pregnancy. The validity of this questionnaire was assessed against the validated FFQ of the SUN project (Seguimiento Universidad de Navarra project) ${ }^{11}$. The "application guide" included information on the typical serving size for each basic food ${ }^{9}$. In order to estimate if both groups fulfilled with the nutritional recommendations for Spanish pregnant women, bread and rice/pasta/potatoes were grouped as cereal products ${ }^{12}$; and nuts, pulses, fish, eggs and meat were grouped as protein products. Qualitative 
information about the consumption of supplements, fortified or functional foods was obtained using different categories.

\section{Data collection}

The questionnaire information was collected by face to face interviews by community pharmacists using a platform located in a website created for this study in order to save the information collected. The questionnaire was completed before the nutrition education. In fact, the nutrition education was based in the main errors identified throughout the questionnaire. Data were refined, processed and analyzed in an anonymous and confidential way. On the 5,711 questionnaires that were received from pregnant women, 624 (10.9\%) were excluded because of missing values on important variables. The final sample for the analysis was 5,087 . It should be noted that the number of cases differed for some of the variables as described (Fig. 1).

Figure 1. Sample size for certain variables

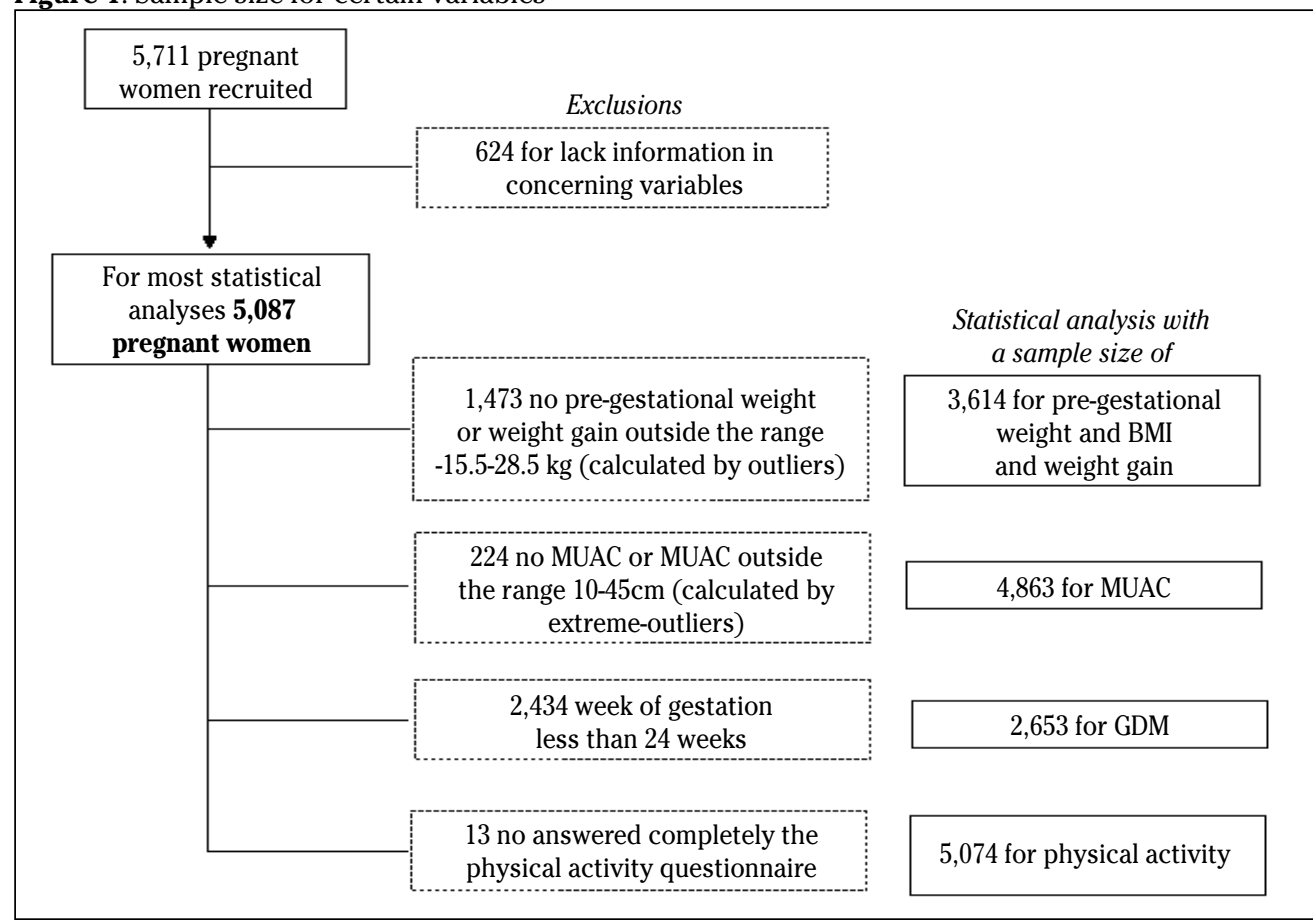

MUAC: Mid-upper arm circumference; BMI: Body mass index; GDM: Gestational diabetes mellitus

\section{Statistical analyses}

Means and standard desviations (SD) were used as descriptive statistics for age, weight, height, BMI, MUAC, physical activity and food habits. Student $t$ tests were performed to compare means for these variables between nulliparous and multiparous women. General linear models of analysis of covariance (ANCOVA) were used to test the differences in quantitative variables by parity status with age, current BMI and gestational age as covariates. Frequencies and $\chi^{2}$ tests were used to compare different proportions of health, toxic habits and other food variables between both groups.

The statistical Package for Social Sciences (SPSS), version 15.0 for WindowsXP was used in the analyses. All p values presented are two-tailed and differences were considered significant at $\mathrm{p}<0.05$. 


\section{RESULTS}

A total of 5,087 pregnant women were analyzed, who were distributed as $56 \%$ nulliparas and $44 \%$ multiparas. Age, gestational age and anthropometrical measurements (preconceptional weight, current weight, weight gain, height, preconceptional BMI, current BMI and MUAC) were studied (Table 1). The average maternal age of the sample was $31.9 \pm 4.6$ years, being lower the age at first maternity. Those nulliparous women presented lower values for preconceptional weight, current weight, preconceptional BMI, current BMI and MUAC after adjusted for age and gestational age. Statistical differences were also observed for the week of gestation, being nulliparous mothers whose showed low gestational age.

Table 1. Anthropometrical measurements stratified by parity status in pregnant women 2009-2010 (Spain)

\begin{tabular}{|c|c|c|c|c|c|c|c|c|c|c|}
\hline & \multicolumn{2}{|c|}{$\begin{array}{c}\text { Total } \\
\text { (n 5,087) }\end{array}$} & \multicolumn{2}{|c|}{$\begin{array}{l}\text { Nullipara } \\
\text { (n 2,849) }\end{array}$} & \multicolumn{2}{|c|}{$\begin{array}{l}\text { Multipara } \\
\text { (n 2,238) }\end{array}$} & \multirow[t]{2}{*}{$\mathbf{p}^{\mathbf{c}}$} & \multirow{2}{*}{$\begin{array}{c}\text { p model } \\
1^{\mathrm{d}}\end{array}$} & \multirow{2}{*}{$\begin{array}{c}\text { p model } \\
2^{d}\end{array}$} & \multirow{2}{*}{$\begin{array}{c}\text { p model } \\
3^{d}\end{array}$} \\
\hline & Mean & SD & Mean & SD & Mean & SD & & & & \\
\hline Age (years) & 31.9 & 4.6 & 30.8 & 4.7 & 33.3 & 4.2 & $<0.001^{*}$ & - & $<0.001^{*}$ & - \\
\hline Gestational age (weeks) & 23.3 & 10.5 & 22.9 & 10.4 & 23.7 & 10.6 & $0.012^{*}$ & 0.222 & - & - \\
\hline $\begin{array}{l}\text { Preconceptional weight } \\
(\mathrm{kg})^{\mathrm{a}}\end{array}$ & 60.6 & 8.6 & 60.2 & 8.3 & 61.2 & 8.8 & $0.002^{*}$ & $0.007^{*}$ & $0.002^{*}$ & $0.008^{*}$ \\
\hline Current weight (kg) & 67.5 & 10.2 & 66.8 & 10.0 & 68.5 & 10.5 & $<0.001^{*}$ & $<0.001^{*}$ & $<0.001^{*}$ & $<0.001^{*}$ \\
\hline Weight gain $(\mathrm{kg})^{\mathrm{a}}$ & 6.4 & 8.5 & 6.4 & 8.4 & 6.5 & 8.6 & 0.502 & 0.520 & 0.994 & 0.318 \\
\hline Height (cm) & 164.1 & 6.1 & 164.1 & 6.1 & 164.0 & 6.2 & 0.311 & 0.495 & 0.331 & 0.507 \\
\hline $\begin{array}{l}\text { Preconceptional BMI } \\
\left(\mathrm{kg} / \mathrm{m}^{2}\right)^{\mathrm{a}}\end{array}$ & 22.6 & 3.0 & 22.4 & 2.3 & 22.8 & 3.2 & $0.001^{*}$ & $<0.001^{*}$ & $<0.001^{*}$ & $<0.001$ * \\
\hline Current BMI $\left(\mathrm{kg} / \mathrm{m}^{2}\right)$ & 25.2 & 4.1 & 24.9 & 4.0 & 25.5 & 4.2 & $<0.001^{*}$ & $<0.001^{*}$ & $<0.001^{*}$ & $<0.001^{*}$ \\
\hline $\operatorname{MUAC}(\mathrm{cm})^{\mathrm{b}}$ & 28.0 & 4.1 & 27.8 & 4.1 & 28.3 & 4.2 & $<0.001^{*}$ & $0.001^{*}$ & $<0.001^{*}$ & $0.002^{*}$ \\
\hline
\end{tabular}

BMI, Body mass index; MUAC, Mid-upper arm circumference

* Statistically significant $(\mathrm{p}<0.05)$

${ }^{\text {a }}$ Data calculated with a sample size of 3,614 (nullipara n 1,607 and multipara n 2,007)

${ }^{\mathrm{b}}$ Data calculated with a sample size of 4,863 (nullipara $\mathrm{n} 2,728$ and multipara $\mathrm{n} 2,135$ )

${ }^{\mathrm{c}} \mathrm{p}$ value Student $\mathrm{t}$ test $(\mathrm{p}<0.05)$

${ }^{\mathrm{d}} \mathrm{p}$ value ANCOVA test $(\mathrm{p}<0.05)$

Model 1: Adjusted for age (years)

Model 2: Adjusted for gestational age (weeks)

Model 3: Adjusted for age (years) and gestational age (weeks)

Obstetric data, health status and other related nutritional issues were also collected (Table 2). Nulliparous mothers showed better self-perceived health status and nutritional balance, presenting as well as less frequency of GDM. As expected, the frequency of previous miscarriage was higher among multiparas. Also, statistical differences were found for educational level between both conceptional conditions (nulliparas versus multiparas). 
Table 2. Health markers and global issues stratified by the parity status in pregnant women 2009-2010 (Spain)

\begin{tabular}{lcccc}
\hline & $\begin{array}{c}\text { Total } \\
\text { (n 5,087) }\end{array}$ & $\begin{array}{c}\text { Nullipara } \\
\text { (n 2,849) }\end{array}$ & $\begin{array}{c}\text { Multipara } \\
\text { (n 2,238) }\end{array}$ & $\mathbf{p}^{\mathbf{b}}$ \\
\hline University degree (\%) & 46.2 & 48.4 & 43.5 & $<0.001^{*}$ \\
\hline Self-perception health status good or very good (\%) & 85.7 & 87.9 & 83.6 & $<0.001^{*}$ \\
\hline Self-perception nutritional balance good or very good (\%) & 86.8 & 88.2 & 85.1 & $0.001^{*}$ \\
\hline Singleton pregnancy (\%) & 96.5 & 96.0 & 97.0 & 0.062 \\
\hline Previous miscarriage (\%) & 17.8 & 13.8 & 22.8 & $<0.001^{*}$ \\
\hline GDM (\%) & 7.8 & 6.7 & 9.2 & $0.017^{*}$ \\
\hline Suffer a severe disease (\%) & 4.3 & 4.1 & 4.5 & 0.568 \\
\hline
\end{tabular}

GDM, Gestational diabetes mellitus

* Statistically significant $(\mathrm{p}<0.05)$

a Data analyzed from 24 gestational age, sample size of 2,653 (nullipara n 1,440 and multipara n 1,213)

${ }^{\mathrm{b}} \mathrm{p}$ value from $\chi^{2}$ test $(\mathrm{p}<0.05)$

Smoking and alcohol consumption were more frequent among nulliparous women. However, this was not observed for declared illicit drugs (Table 3). Regarding to physical activity, some differences were noted, being physical activity patterns in multiparous women more active after adjusted for age, current BMI and gestational age (Table 3).

Table 3. Unhealthy lifestyles and physical activity pattern stratified by the parity status in pregnant women 2009-2010 (Spain)

\begin{tabular}{|c|c|c|c|c|c|c|c|c|c|c|c|}
\hline & \multicolumn{2}{|c|}{$\begin{array}{c}\text { Total } \\
\text { (n 5,087) }\end{array}$} & \multicolumn{2}{|c|}{$\begin{array}{l}\text { Nullipara } \\
\text { (n 2,849) }\end{array}$} & \multicolumn{2}{|c|}{$\begin{array}{c}\text { Multipara } \\
\text { (n 2,238) }\end{array}$} & \multirow[t]{2}{*}{$\mathbf{P}^{\mathbf{b}}$} & \multirow{2}{*}{$\begin{array}{c}\text { p model } \\
1^{\mathrm{d}}\end{array}$} & \multirow{2}{*}{$\begin{array}{c}\text { p model } \\
2^{d}\end{array}$} & \multirow{2}{*}{$\begin{array}{c}\text { p model } \\
3^{\mathrm{d}}\end{array}$} & \multirow{2}{*}{$\underset{4^{d}}{p \text { model }}$} \\
\hline & Mean & SD & Mean & SD & Mean & SD & & & & & \\
\hline Smoking (\%) & 32.9 & & 34.9 & & 30.3 & & $0.001^{*}$ & - & - & - & - \\
\hline Alcohol (\%) & 24.6 & & 27.3 & & 21.1 & & $<0.001^{*}$ & - & - & - & - \\
\hline Illicit drugs (\%) & 1.8 & & 1.9 & & 1.7 & & 0.686 & - & - & - & - \\
\hline Special diet (\%) & 14.3 & & 13.0 & & 15.9 & & $0.004^{*}$ & - & - & - & - \\
\hline Hours/day lyinga & 9.1 & 1.8 & 9.3 & 1.8 & 8.8 & 1.7 & $<0.001^{* \mathrm{c}}$ & $<0.001^{*}$ & $<0.001^{*}$ & $<0.001^{*}$ & $<0.001^{*}$ \\
\hline Hours/day sitting ${ }^{\mathrm{a}}$ & 6.4 & 2.5 & 6.6 & 2.5 & 6.1 & 2.6 & $<0.001^{* c}$ & $<0.001^{*}$ & $<0.001^{*}$ & $<0.001^{*}$ & $<0.001^{*}$ \\
\hline $\begin{array}{l}\text { Hours/day standing } \\
\text { or moving }^{\text {a }}\end{array}$ & 8.5 & 2.9 & 8.1 & 2.7 & 9.1 & 2.9 & $<0.001^{* \mathrm{c}}$ & $<0.001^{*}$ & $<0.001^{*}$ & $<0.001^{*}$ & $<0.001^{*}$ \\
\hline
\end{tabular}

* Statistically significant $(\mathrm{p}<0.05)$

aData calculated with a sample size of 5,074 (nullipara n 2,843 and multipara n 2,231)

${ }^{\mathrm{b}}$ pvalue from $\chi^{2}$ test $(\mathrm{p}<0.05)$

${ }^{\mathrm{c}} \mathrm{p}$ value from Student $\mathrm{t}$ test $(\mathrm{p}<0.05)$

${ }^{\mathrm{d}} \mathrm{p}$ value ANCOVA test $(\mathrm{p}<0.05)$

Model 1: Adjusted forg estational age (weeks)

Model 2: Adjusted for age (years) and current BMI $\left(\mathrm{kg} / \mathrm{m}^{2}\right)$

Model 3: Adjusted for current BMI $\left(\mathrm{kg} / \mathrm{m}^{2}\right)$ and gestational age (weeks)

Model 4: Adjusted for age (years), current BMI $\left(\mathrm{kg} / \mathrm{m}^{2}\right)$ and gestational age (weeks) 
Interestingly, for food consumption statistical differences were observed in model 4 (adjusted forage, current BMI and gestational age) between the two groups (nulliparas versusmultiparas) concerning dairy products, fresh fruit, bread, rice/pasta/potatoes, nuts, meat, sausage and buns/ pastries (Table 4). The adherence to the recommended number of servings for the Spanish pregnant women was also analyzed. Both groups, consumed fewer servings of dairy products (2.26 servings/day), salads/vegetables (1.26 servings/day) and cereal products (2.39 servings/day) than the minimum recommendations: 3,2 and 4 servings/day respectively (data not showed). On the other hand, statistical differences were found for the intake of olive oil and sweeteners (Table 5). Nevertheless, these differences were not detected regarding fortified food and nutritional supplements consumption except supplements of iron (Table 5).

Table 4. Food consumption (number of servings) stratified by the parity status in pregnant women 2009-2010 (Spain)

\begin{tabular}{|c|c|c|c|c|c|c|c|c|c|c|c|}
\hline & \multicolumn{2}{|c|}{$\begin{array}{c}\text { Total } \\
\text { (n 5,087) }\end{array}$} & \multicolumn{2}{|c|}{$\begin{array}{c}\text { Nullipara } \\
\text { (n 2,849) }\end{array}$} & \multicolumn{2}{|c|}{$\begin{array}{c}\text { Multipara } \\
\text { (n 2,238) }\end{array}$} & \multirow[t]{2}{*}{$\mathbf{p}^{\mathrm{c}}$} & \multirow{2}{*}{$\begin{array}{c}\text { p model } \\
1^{\mathrm{d}}\end{array}$} & \multirow{2}{*}{$\begin{array}{c}\text { p model } \\
2^{d}\end{array}$} & \multirow{2}{*}{$\begin{array}{c}\text { p model } \\
3^{\text {d }}\end{array}$} & \multirow{2}{*}{$\begin{array}{c}\text { p model } \\
4^{d}\end{array}$} \\
\hline & Mean & SD & Mean & SD & Mean & SD & & & & & \\
\hline Dairy products $^{\mathrm{a}}$ & 2.3 & 1.3 & 2.3 & 1.2 & 2.2 & 1.3 & 0.133 & 0.107 & $0.034^{*}$ & 0.137 & $0.033^{*}$ \\
\hline Salads/Vegetables ${ }^{\mathrm{a}}$ & 1.3 & 1.0 & 1.2 & 1.0 & 1.3 & 1.0 & 0.358 & 0.361 & 0.488 & 0.345 & 0.487 \\
\hline Fresh fruit $^{\mathrm{a}}$ & 2.0 & 1.4 & 2.1 & 1.3 & 2.0 & 1.4 & 0.051 & $0.041^{*}$ & $<0.001^{*}$ & 0.053 & $<0.001^{*}$ \\
\hline Bread $^{\mathrm{a}}$ & 1.7 & 1.2 & 1.7 & 1.2 & 1.8 & 1.3 & $0.007^{*}$ & $0.004^{*}$ & $0.003^{*}$ & $0.006^{*}$ & $0.003^{*}$ \\
\hline Rice/Pasta/Potatoes ${ }^{\mathrm{a}}$ & 0.7 & 0.7 & 0.6 & 0.6 & 0.7 & 0.7 & $0.012^{*}$ & $0.013^{*}$ & $0.001^{*}$ & $0.004^{*}$ & $0.001^{*}$ \\
\hline Nuts $^{\mathrm{b}}$ & 2.0 & 3.3 & 2.1 & 3.3 & 1.9 & 3.2 & $0.003^{*}$ & $0.003^{*}$ & $0.001^{*}$ & $0.005^{*}$ & $0.001^{*}$ \\
\hline Pulses $^{b}$ & 2.4 & 2.7 & 2.4 & 2.8 & 2.4 & 2.6 & 0.751 & 0.791 & 0.921 & 0.766 & 0.917 \\
\hline Fish $^{\mathrm{b}}$ & 3.2 & 3.3 & 3.2 & 3.3 & 3.3 & 3.2 & 0.541 & 0.359 & 0.631 & 0.334 & 0.633 \\
\hline Eggs $^{b}$ & 2.5 & 1.6 & 2.5 & 1.6 & 2.5 & 1.6 & 0.949 & 0.547 & 0.338 & 0.372 & 0.338 \\
\hline Meat $^{b}$ & 4.3 & 3.5 & 4.2 & 3.3 & 4.4 & 3.7 & $0.011^{*}$ & $0.010^{*}$ & $0.004^{*}$ & $0.014^{*}$ & $0.004^{*}$ \\
\hline Sausage $^{\mathrm{b}}$ & 2.6 & 3.5 & 2.5 & 3.4 & 2.8 & 3.6 & $0.002^{*}$ & $0.001^{*}$ & $<0.001^{*}$ & $0.002^{*}$ & $<0.001^{*}$ \\
\hline Buns/Pastries ${ }^{\mathrm{b}}$ & 2.6 & 4.1 & 2.5 & 4.0 & 2.7 & 4.2 & 0.100 & 0.092 & $<0.001^{*}$ & 0.107 & $<0.001^{*}$ \\
\hline
\end{tabular}

* Statistically significant $(\mathrm{p}<0.05)$

${ }^{a}$ Daily consumption; ${ }^{\text {b }}$ Weekly consumption; ${ }^{c} p$ value from Student $t$ test $(\mathrm{p}<0.05) ;{ }^{\mathrm{d}} \mathrm{p}$ value ANCOVA test $(\mathrm{p}<0.05)$

Model 1: Adjusted for gestational age (weeks)

Model 2: Adjusted for age (years) and current BMI $\left(\mathrm{kg} / \mathrm{m}^{2}\right)$

Model 3: Adjusted for current BMI $\left(\mathrm{kg} / \mathrm{m}^{2}\right)$ and gestational age (weeks)

Model 4: Adjusted for age (years), current BMI $\left(\mathrm{kg} / \mathrm{m}^{2}\right)$ and gestational age (weeks)

Table 5. Regular consumption of fortified foods, nutritional supplements, olive oil and caloric sweeteners stratified by the parity status in pregnant women 2009-2010 (Spain)

\begin{tabular}{lcccc}
\hline & Total (n 5,087) & Nullipara (n 2,849) & Multipara (n 2,238) & $\mathbf{p}^{\mathbf{a}}$ \\
\hline Fortified milk (\%) & 24.9 & 24.6 & 25.3 & 0.550 \\
\hline Fiber / Prebiotics (\%) & 13.2 & 13.5 & 12.9 & 0.500 \\
\hline Probiotics(\%) & 5.4 & 5.3 & 5.6 & 0.656 \\
\hline Iodine/Iodized salt(\%) & 41.3 & 41.7 & 40.9 & 0.575 \\
\hline Folicacid / vitamin $\mathrm{B}_{12}(\%)$ & 74.7 & 75.6 & 73.5 & 0.092 \\
\hline Iron (\%) & 46.1 & 44.9 & 47.7 & $0.042^{*}$ \\
\hline Polivitam/ Mineral (\%) & 26.7 & 27.1 & 26.2 & 0.448 \\
\hline Olive oil (\%) & 92.9 & 93.9 & 91.6 & $0.001^{*}$ \\
\hline Sugar, Honey or Fructose (\%) & 75.2 & 76.6 & 73.5 & $0.014^{*}$ \\
\hline
\end{tabular}

* Statistically significant $(\mathrm{p}<0.05) ;{ }^{\text {a }} \mathrm{p}$ value from $\chi^{2}$ test $(\mathrm{p}<0.05)$ 


\section{DISCUSSION}

The results of this epidemiological research from 5,087 pregnant women showed differences between nulliparous and multiparous mothers regarding to nutritional status, sociodemographic features, lifestyle behaviors and dietary habits.

After adjusted for age and gestational age, the current differences on anthropometrical variables between the two different profiles of Spanish pregnant women were observed. The mean value of preconceptional body weight and BMI variables were in the normal range in both groups ${ }^{13,14}$. However, higher preconceptional body weight and BMI were found in multiparous women. This finding could be associated with the body weight retention in the postpartum period, which has been reported between 0.5 and $3.8 \mathrm{~kg}^{15}$. Moreover, multiparous women presented higher values of current weight and BMI than nulliparous women, although there were not found statistical differences between groups regarding to weight gain during pregnancy. In this sense, pre-pregnancy BMI, parity and weight gain during pregnancy have been identified as contributors of the increase of the prevalence of overweight and obesity among women ${ }^{3}$.

Besides the weight and BMI, MUAC is another anthropometrical measurement ofinterest during pregnancy, mainly because of its relationship with low birth weight $(<2,500 \mathrm{~g})$ but also with disproportionate low intrauterine growth, preterm birth/labor, birth asphyxia and small for gestational age ${ }^{16}$. A recent systematic review showed that, regarding to low birth weight, most of the studies used MUAC cutoffs ranging from 22 to $24 \mathrm{~cm}^{16}$. However, we can not compare our results with these studies since they did not include European populations.

Educational level and other socioeconomic features have an impact on maternal and child health ${ }^{17}$. A high level of education implies a better access and understanding of the information about the benefits of following healthy habits during pregnan$\mathrm{cy}^{17}$. In our research, there were a lower percentage of multiparas with a university degree than nulliparas. So, it can be speculated that multiparous mothers and their offsprings are more vulnerable to present adverse health effects.

The results of the subjective assessment (self-perception of the global health status and nutritional balance) appear to be in accordance with the results obtained later related to special diet consumption. Multiparas presented worse self-perception in health status and nutritional balance, probably thus they followed more a special diet compared with nulliparas.

In our research, the prevalence of GDM was higher in multiparous women than in nulliparous once. In one hand, a previous research found that women with GDM in their first pregnancy were at increased risk for developing GDM in their subsequent pregnancies $^{7}$. This study also observed that the risk of GDM is higher in subsequent pregnancies. On the other hand, has been reported that women who gain more BMI units between their first and second pregnancy showed a higher risk of developing GDM in their second pregnancy ${ }^{18}$. In accordance with these evidences, we noted that multiparous women presented higher prepregnancy and current BMI than nulliparous women. Moreover, parity plays a key role in the development of GDM. So, it may be suggested that the high prevalence of GDM in multiparas could be due to the parity and the higher prepregnancy and current BMI of this group of pregnant women.

Regarding to lifestyle habits, there were several differences between the two profiles analyzed, being multiparous women the group that presented healthier behaviors. In our research contrasting with previous investigations in Spanish pregnant women, multiparous mothers smoked less than nulliparous ${ }^{19,20}$. Also, alcohol and illicit drugs consumption was lower among multiparous women, although concerning illicit drugs not statistical differences were observed. The results about these three lifestyle habits may be related, given that the research of Erickson et $\mathrm{al}^{21}$ supported that heavy smokers have an increased risk of being identified for alcohol and illicit drug use. 
In a different way, after adjusted for age, current BMI and gestational age, we observed that nulliparous women were more sedentary than those multiparous. Our findings about the hours lying or sleeping are in accordance with the research of Borodulin et al in which nulliparous women reported longer sleep duration and better sleep quality ${ }^{22}$. Moreover, a recent study of 1,259 pregnant women found that multiparous mothers had higher odds of participating in strenuous physical activity and they also reported a lower decrease in physical activity level during pregnancy than nulliparous mothers ${ }^{8}$.

To our knowledge, there are few studies that analyzed the differences in the type of food intake by parity ${ }^{23-26}$. In general, in our population (after adjusted for age, current BMI and gestational age) nulliparas followed a healthier diet than multiparas, which is consistent with other findings reported on a healthy conscious diet (characterized by a high consumption of vegetables, fruits, cereals, fish and pulses) is negatively associated with increased parity ${ }^{23}$. Moreover, a caloric diet pattern has been positively associated with parity ${ }^{24}$. In this context, nulliparous mothers consumed healthier food groups as fruits ${ }^{25}$, dairy products, nuts and olive oil, but also more caloric sweeteners. On the other hand, multiparas women consumed more energy-dense and rich in unhealthy fat food groups than nulliparas, as meat, sausages ${ }^{26}$, and buns/pastries, but also more rice/pasta/potatoes and bread. Although the differences among diet intake were statistically significant, we could not consider them clinically relevant from a dietary point of view.

When the dietary consumption was compared with the recommendations for Spanish pregnant women, it was observed a lower intake of dairy products, salads/ vegetables and cereal products than it is recommended $^{12}$. Different studies have been carried out to determine the adherence to the dietary recommendations in pregnant women. Similarly to our results Ferrer et al showed that cereals, vegetables and pulses consumption was below the portions recommended, among Span- ish pregnant women ${ }^{24}$. Additionally, Wilkinson et al reported that the consumption of vegetables and also fruits was below the daily portions recommend in Australian pregnant women ${ }^{27}$. In contrast, Ortiz-Andrellucchi et al found in a Spanish population that pregnant women consumed more vegetables, fruit, milk and meat products than the recommendations, but less cere$\mathrm{als}^{28}$. However, these data can not be strictly compared with each other because each country (or group of countries) has their own recommendations, even there is more than one organism that stablishs different dietary references within the same country, as in Spain ${ }^{1}$.

Finally, concerning supplementation there were not statistically significant differences in any type of supplement except in iron, being multiparous mothers those who consumed more. This outcome may be explained because anaemic pregnant women are administered more iron supplements. However, few studies concluded that parity is associated with anaemia, although Bencaiova et al reported that it is a risk factor of decreasing of iron stores ${ }^{29}$.

The present study has some limitations. The main one is the origin of the recruitment of the volunteers (pharmacies), which may have resulted in a not totallyrepresentative sample. However, the large sample size should support the validity of our investigation as well as the low margin of error in this population. And the fact that this enrollment protocol has been previously applied in prior studies ${ }^{30}$. Another limitation is the gestational age variability between groups; nevertheless we adjusted all of our analysis for this variable, and also for age and current BMI. In order to implement the nutritional questionnaire, community pharmacists received a training session by videoconference or face to face. Although the interviewers received the information by two different ways, all of them received the same application guide to give consistency to the survey. Moreover, we recognize that the statistical differences in the intake of some groups of food by parity are small. Nonetheless, these findings provide an overview of the trends in the con- 
sumption of certain type of foods, among Spanish pregnant women. In spite of these limitations; the strength of our study is that we used a FFQ and physical activity questionnaire both validated specially for the target population group ${ }^{11}$. Furthermore, the main anthropometric measurements have also been validated ${ }^{11}$.

In summary, differences associated to parity were observed in nutritional status, sociodemographic features, lifestyle behaviors, and dietary habits. Multiparous women presented healthier lifestyle behaviors and a more active physical activity pattern than nulliparous. However, nulliparous women consumed more foods rich in vitamins and minerals (dairy products and fruit), while multiparous intaked more rich energy-dense foods (meat, sausage, buns/ pastries). Thus, these findings provide some insights into the design of programs aimed at promoting healthy lifestyles habits during pregnancy according to parity.

\section{Acknowledgements}

The authors thank all the pharmacists that participated in the data collection and the women who agreed to participate voluntarily in this study. The authors also wish to thank the CIBERobn/RETICS schedules (Instituto Carlos III) assistance in this study.

\section{REFERENCES}

1. Cuervo M, Baladia E, Goñ L, Corbalán M, ManERA M, BASUlto J et al. Propuesta de ingestas dietéticas de referencia (IDR) para la población española. In: Federación Española de Sociedades de Nutrición, Alimentación y Dietética (FESNAD), editor. Ingestas Dietéticas de Referencia (IDR) para la población española. España: EUNSA; 2010:263-341.

2. HovdenaK $\mathrm{N}$, HARAM $\mathrm{K}$. Influence of mineral and vitamin supplements on pregnancy outcome. Eur J Obstet Gynecol Reprod Biol 2012; 164:127-32.

3. Melzer K, Schutz Y. Pre-pregnancy and pregnancy predictors of obesity. Int $\mathrm{J}$ Obes (Lond) 2010; (Suppl. 2): 44-52.

4. Huarte Ciganda M, Modroño A, Larrañaga C. Management of hypertension in pregnancy. An Sist Sanit Navar 2009;32 (Suppl 1): 91-103.
5. Wendell AD. Overview and epidemiology of substance abuse in pregnancy. Clin Obstet Gynecol 2013; 56: 91-96.

6. Melzer K, Schutz Y, Boulvain M, Kayser B. Physical activity and pregnancy: Cardiovascular adaptations, recommendations and pregnancy outcomes. Sports Med 2010;40:493-507.

7. Getahun D, Fassett MJ, Jacobsen SJ. Gestational diabetes: Risk of recurrence in subsequent pregnancies. Am J Obstet Gynecol 2010;203:467.

8. Liu J, Blair SN, Teng Y, Ness AR, Lawlor DA, Riddoch C. Physical activity during pregnancy in a prospective cohort of British women: Results from the Avon Longitudinal Study of Parents and Children. Eur J Epidemiol 2011;26:237-247.

9. IV plan de educación nutricional en el periodo pre-concepcional, embarazo y lactancia [Internet]. Available from: http://www.portalfarma.com/Profesionales/campanaspf/categorias/Paginas/Alimentacion/planeducacionplenufar4.aspx. (Accessed 30/03/2014).

10. World Medical Association. World medical association declaration of helsinki: Ethical principles for medical research involving human subjects. JAMA 2013;310:2191-2194.

11. Goni L, Martínez JA, Santiago S, Cuervo M. Validation of a questionnaire to assess the nutritional status and lifestyles in stages of preconception, pregnancy and lactation. Rev Esp Nutr Comunitaria 2013; 19:105-113.

12. Dapcich V, Salvador G, Ribas L, Pérez C, Aranceta J, SERRA L. Guía de la alimentación saludable. Madrid; 2004.

13. Ricart W, Gonzalez-Huix F, Conde V. Evaluation of the nutritional status through determination of anthropometric parameters: New charts for the working population of Catalonia. group for the evaluation of body composition in the population of Catalonia. Med Clin (Barc) 1993; 100:681-691.

14. Rubio MA, Salas-Salvadó J, Barbany M, Moreno B, Aranceta J, Bellido D et al. Consenso SEEDO 2007 para la evaluación del sobrepeso y la obesidad y el establecimiento de criterios de intervención terapéutica. Rev Esp Obes 2007: 1: 7-48.

15. LinNe Y, Rossner S. Interrelationships between weight development and weight retention in subsequent pregnancies: The SPAWN study. Acta Obstet Gynecol Scand 2003;82:318-325.

16. Tang AM, Dong K, Deitchler M, Chung M, MaAlouf-Manasseh Z, Tumilowicz A et al. Use of cutoffs for mid-upper arm circumference (MUAC) as an indicator or predictor of nutritional and health-related outcomes in ad- 
olescents and adults: A systematic review. Washington, DC, 2013.

17. Larranaga I, Santa-Marina L, Begiristain H, MaCHON M, VRIJHEID M, CASAS M et al. Socio-economic inequalities in health, habits and self-care during pregnancy in Spain. Matern Child Health J 2013; 17: 1315-1324.

18. Ehrlich SF, Hedderson MM, Feng J, Davenport ER, Gunderson EP, Ferrara A. Change in body mass index between pregnancies and the risk of gestational diabetes in a second pregnancy. Obstet Gynecol 2011;117:1323-1330.

19. Palma S, Perez-Iglesias R, Pardo-Crespo R, Llorca J, Mariscal M, Delgado-Rodriguez M. Smoking among pregnant women in Cantabria (Spain): Trend and determinants of smoking cessation. BMC Public Health 2007;7:65.

20. Villalbi JR, Salvador J, Cano-Serral G, RodriGuEz-SANz MC, Borrell C. Maternal smoking, social class and outcomes of pregnancy. Paediatr Perinat Epidemiol 2007;21:441-447.

21. ERICKSON AC, Arbour LT. Heavy smoking during pregnancy as a marker for other risk factors of adverse birth outcomes: A population-based study in British Columbia, Canada. BMC Public Health 2012;12:102.

22. Borodulin K, Evenson KR, Monda K, Wen F, HerRING AH, Dole N. Physical activity and sleep among pregnant women. Paediatr Perinat Epidemiol 2010;24:45-52.

23. Northstone K, Emmett P, Rogers I. Dietary patterns in pregnancy and associations with socio-demographic and lifestyle factors. Eur J Clin Nutr 2008;62:471-479.
24. Ferrer C, García-Esteban R, Méndez M, Romieu I, TORRENT M, SunYer J. Social determinants of dietary patterns during pregnancy. Gac Sanit 2009;23:38-43.

25. Bodnar LM, SiEga-Riz AM. A diet quality index for pregnancy detects variation in diet and differences by sociodemographic factors. Public Health Nutr 2002; 5:801-809.

26. Uusitalo L, Uusitalo U, Ovaskainen ML, Ninisto S, Kronberg-KipPILA C, MarJamaKi L et al. Sociodemographic and lifestyle characteristics are associated with antioxidant intake and the consumption of their dietary sources during pregnancy. Public Health Nutr 2008;11:13791388.

27. WilKinson SA, McInTYRe HD. Evaluation of the "healthy start to pregnancy" early antenatal health promotion workshop: A randomized controlled trial. BMC Pregnancy Childbirth 2012;12: 31 .

28. Ortiz-Andrellucchi A, Sanchez-Villegas A, Ramirez-García O, Serra-Majem L. Assessment of nutritional quality in healthy pregnant women of the Canary Islands, Spain. Med Clin (Barc) 2009;133:615-621.

29. Bencaiova G, Burkhardt T, Breymann C. Anemia-prevalence and risk factors in pregnancy. Eur J Intern Med 2012;23:529-533.

30. Cuervo M, García A, Ansorena D, SÁnchez-Villegas A, Martínez-González M,Astiasarán I, MartínEZ JA.Nutritional assessment interpretation on 22,007 Spanish community-dwelling elders through the Mini Nutritional Assessment tes. Public Health Nutr 2009; 12: 82-90. 
Appendix 1 .

Pregnant women distribution by region

\begin{tabular}{lc}
\hline \multicolumn{1}{c}{ Region } & n (\%) \\
\hline Andalucía & $700(13.8)$ \\
\hline Aragón & $424(8.3)$ \\
\hline Asturias & $69(1.4)$ \\
\hline Cantabria & $70(1.4)$ \\
\hline Castilla la Mancha & $716(14.1)$ \\
\hline Castilla y León & $561(11.0)$ \\
\hline Cataluña & $577(11.3)$ \\
\hline Comunidad Valenciana & $122(2.4)$ \\
\hline Extremadura & $80(1.6)$ \\
\hline Galicia & $390(7.7)$ \\
\hline Islas Baleares & $23(0.5)$ \\
\hline Islas Canarias & $194(3.8)$ \\
\hline La Rioja & $45(0.9)$ \\
\hline Madrid & $539(10.6)$ \\
\hline Melilla & $19(0.4)$ \\
\hline Murcia & $182(3.6)$ \\
\hline Navarra & $43(0.8)$ \\
\hline País Vasco & \\
\hline & \\
\hline
\end{tabular}


Appendix 2.

\section{Nutritional questionnaire \\ ENCUESTA NUTRICIONAL \\ EN SITUACIÓN DE EMBARAZO}

\section{DATOS GENERALES}

Edad de la mujer: años Altura: $\mathrm{cm}$

Peso pre-gestacional: $\mathrm{kg}$

Peso actual de la mujer: kg Circunferencia del brazo: $\mathrm{cm}$

№ hijos nacidos: $\square 0 \quad \square 1 \quad \square 2 \quad \square 3$ ó más

Nivel de estudios: $\square$ Sin estudios $\quad \square$ Primarios $\quad \square$ Bachillerato o F.P. $\square$ Titulación universitaria ¿Cómo considera que es su salud actual comparada con la de otras mujeres en su situación?

$\square$ Muybuena $\square$ Buena $\square$ Regular $\square$ Mala $\square$ Muy mala $\square$ NS/NC

¿Cómo considera que es su alimentación actual comparada con la de otras mujeres en su situación? $\square$ Equilibrada $\square$ Bastante equilibrada $\square$ Poco equilibrada $\square$ Muy desequilibrada $\quad \square$ NS/NC

Actividad física en un día típico (horas totales):

Horas tumbada o dormida:

Horas de actividades sentada:

Horas de actividades de pie o en movimiento:

\section{INFORMACIÓN OBSTÉTRICA}

Tipo de embarazo: $\square$ Único $\square$ Gemela $\square$ Triple o más

Semana de gestación: semanas (2-42)

Paridad: $\square 1^{\circ}$ embarazo $\square 2^{\circ}$ embarazo $\square 3^{\circ}$ embarazo o más

Proximidad entre embarazos: $\square<$ de 1 año $\quad \square \geq 1$ año

Abortos previos: $\square 0 \quad \square 1 \quad \square>$ de 1

Antecedentes de bajo peso al nacer: $\square$ Sí $\square$ No

\section{INFORMACIÓN DE LA LACTANCIA}

Tipo de lactancia prevista (meses):
$\square$ Materna 0-3 m
$\square$ Materna 0-6 m
$\square$ Artificial 0-6 m
$\square$ Mixta 0-3 m
$\square$ Mixta 0-6 m

HÁBITOS

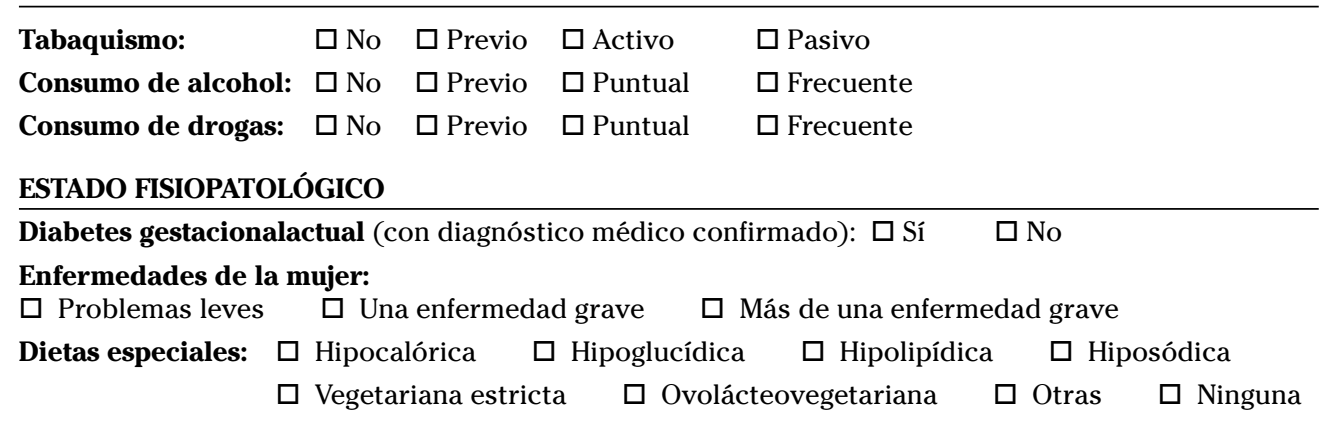




\section{HÁBITOS ALIMENTARIOS}

Frecuencias de consumo: nunca (0)/ mensual (1, 2 ó 3) /semana (1, 2, 3, 4, 5 ó 6) /diario (1, 2, 3, 4, 5, 6 o más)

Lácteos

Huevos

Carnes

Embutidos y fiambres

Pescados

Ensaladas y Verduras
Frutas

Frutos secos

Legumbres

Pan

Arroz, pasta y patatas

Bollería y repostería industrial

\section{Suplementación de la dieta:}

$\square$ Leche enriquecida en calcio/vitaminas

$\square$ Fibra/Prebióticos $\quad \square$ Probióticos $\square$ Yodo/Sal yodada

$\square$ Ácido fólico/Vitamina B12

$\square$ Hierro

$\square$ Polivitamínicos y minerales

$\square$ Ninguno

Tipo de grasa más utilizada para aliñar/cocinar:

$\square$ Oliva virgen $\square$ Oliva $\quad \square$ Girasol $\quad \square$ Mantequilla $\square$ Margarina

Tipo de Edulcorante más utilizado para endulzar alimentos/ bebidas:

$\square$ Azúcar $\square$ Miel $\square$ Fructosa $\square$ Sacarina $\square$ Ninguno 